emplaced before the second unconformity; so that Cullis's and Edge's hypothesis ${ }^{3}$ that they were impounded by the sediments which sometimes overlie them can no longer be sustained.

(6) The intense Tauric folding which produced the Kyrenia (Northern) Range is approximately at right angles to the Troödos folding.

(7) There has been recent rejuvenation of valleys in the Troödos area, which have been scoured out, leaving a few high-level gravel terraces and making slit-trench bottoms with walls much steeper than the usual angle of rest.

(8) The apparent thickness of the Folded Diabase Series is demonstrably more than $5,000 \mathrm{ft}$. and may well exceed 10,000 ft.; but one does not know what deductions to make for dykes and sheets of material introduced lit-par-lit, and for the possibility of repetition by isoclinal folding. On the northern side of the range, pillow lavas have not yet been met at more than $1,200 \mathrm{ft}$. above sea-level, though this height appears to be exceeded on the southern flank where non-spilitic types such as agglomerates are more common. The thickness of the basal volcanics (andesites) which preceded the true pillow lavas may be of the order of $200 \mathrm{ft}$. in a limited area examined south of Karavostasi Port. Having regard to the seaward slope of the old surface over which the pillow lavas were emptied, it is difficult to assign to them, on the average, an excessively great thickness; possibly $2,000 \mathrm{ft}$. would be of the right order of magnitude on the northern side of the range, at their present stage of denudation.

(9) Bailey and McCallien 4 have laid some stress on the occurrence of the 'Steinmann Trinity'-radiolarite, pillow lava, and serpentine-in Turkey; but while these types are well represented in Cyprus, it appears that $(a)$ they have been shielded from the extreme structural disturbances described in Turkey ; (b) the Cyprus radiolarites are assigned to the Triassic; and (c) the serpentine of Troödos is of batholithic form and size and is probably older. This contrasts with conditions described in Turkey.

(10) The age of the Cyprus pillow lavas is admittedly pre-Maestrichtian. The Mamonia formation as described by Henson ${ }^{2}$ contains, inter alia, red beds, tuffs and other volcanic material, and a Triassic fauna, so that its age is not in doubt. The Geological Survey has found similar red beds at points on the south-eastern and eastern margins of the massif, apparently interstratified with pillow lavas and agglomerates, and must conclude that at least a major part of the lavas is Triassic in age. In fact, the Triassic sedimentation was interrupted by this great volcanic phase ; it produced a land surface which was afterwards denuded, and sedimentation was not resumed until it had sunk beneath the engulfing Upper Senonian sea. This land surface under the Lapithos limestones was still somewhat rugged, as the mapping shows. The vulcanism was of no mean order; the old crystalline core must have had a fiery perimeter more than 150 miles long, and we do not know how far the extrusive activity stretched away from it.

(11) Comparisons of Cyprus with the Turkish and Syrian mainlands must be made with reserve at this stage. It is evident that Cyprus is the meeting place of two major tectonic systems : that of Troödos appears to be an ancient orogeny aligned with the African Rift Valley structures the trend of which is dominantly north and south. The Troödos massif acted as a resistant foreland to the much later
Tauric pressure which produced the Kyrenia Range and probably the east to west thrust-traces and shattering in the Folded Diabase Series. The latter, as yet undatable but pre-Triassic, seems to be by far the oldest rock present. The history of the vertical movements of the island remains to be studied.

A report of anything resembling the Folded Diabase Series in the Eastern Mediterranean area would be of extreme interest. The petrology of this great mass of rocks remains to be studied in detail. It is not impossible that careful work may disclose material of sedimentary origin in the formation, but none has yet appeared.

No important occurrence of acid eruptives is known to exist in Cyprus, though a few quartz-bearing dykes have been noticed, and there are some very restricted occurrences of pitchstone and tachylite.

The great positive gravity anomaly due to the Troödos massif has long been known and adduced as evidence of the deep-seated character of its basic rocks. The latter would now be inferred regardless of geophysical evidence. The concept of Kober and others that, in the eastern Mediterranean, "Eurasia and Indo-Africa are sharply and uncompromisingly thrust against one another" is beautifully demonstrated in Cyprus, where the last wave of the Tauric pressure expended itself in vain against one of the most rigid rock-structures known-pre-folded and compressed epidiorite-and left the Kyrenia Range as its monument. The sediments south of the Troödos massif are, as one would expect, but little affected behind such a shield.

The present main objective of the Geological Survey is to produce a detailed map during the next few years, with special reference to the Troödos complex and its associated mineral deposits.

[Dec. 19.

${ }^{1}$ Geological Map of Cyprus, 4 miles to 1 in., 1946. R. V. Browne and J. McGinty, 42nd Geological Section, S.A.E.C., G.H.Q., M.E.F. ${ }^{2}$ Henson, F. R. S., Browne, R. V., and McGinty, J., Q. J. Geol. Soc., 105, 1 (1949). 3 Cullis, C. G., and Broughton Edge, A., Report on the Cupriferous.
Deposits of Cyprus (London : Crown Agents, 1927).

4 Bailey, Sir Edward, and MeCallien, W. J., Nature, 166, 938 (1950).

\section{RADIO EMISSION FROM THE ANDROMEDA NEBULA}

A PAPER by R. Hanbury Brown and C. Hazard $A$ on "Radio Emission from the Andromeda Nebula" has recently been published (Mon. Not. Roy. Astro. Soc., 111, No. 4; 1951), and gives a very full account of the measurements of the radiofrequency radiation from the Great Nebula in Andromeda, using a wave-length of $1.89 \mathrm{~m}$. Reber's attempt to detect such radiation by using a paraboloid of aperture $30 \mathrm{ft}$. on a wave-length of $1.87 \mathrm{~m}$. was unsuccessful; but during the past few years a larger paraboloid of aperture $218 \mathrm{ft}$. and focal length $126 \mathrm{ft}$. has been installed at the Jodrell Bank Experimental Station of the University of Manchester, and the results, described in the paper, have been very satisfactory.

An account of the apparatus, with a block diagram, and also a polar diagram of the $218-\mathrm{ft}$. paraboloid, are given, followed by a description of the method of observation. The beam was fixed at a number of different elevations corresponding to the region around $M 31$, so that it swept out a strip of sky $2^{\circ}$ wide in declination and $24 \mathrm{hr}$. in right ascension, the 
intensity of the radio flux received being recorded continuously for each elevation of the beam for about $100-200 \mathrm{hr}$. Of ninety records obtained, twenty were spoiled by the effects of rain during August and September 1950, and fifty of the remaining records showed the existence of a localized source of radio frequency at right ascension $00 \mathrm{~h} .40 \mathrm{~m}$.

The results afford conclusive evidence that the observed source lies close to the centre of $M 31$, the right ascension being that given above and the declination N. $41^{\circ}$, Epoch 1950, and the apparent dimensions of the source are consistent with a source of radio frequency comparable with the main body of $M 31$. It is most improbable that the finite width of the source is due to a coincidence of two point sources. A comparison of the measured intensity of the emission with that to be expected if $M 31$ is similar to the galaxy is made on the assumption that the mass of $M 31$ lies between $3 \times 10^{10}$ and $10^{11}$ solar masses compared with $10^{11-2} \times 10^{11}$ for the galaxy, and on such assumption the intensity of the radio frequency from $M 31$ would be expected to lie between $10^{-24}$ and $7 \times 10^{-24}$ W. m..$^{-2}(\mathrm{c} . / \mathrm{s} .)^{-1}$, which include the observed values. The agreement suggests that M31 possesses similar characteristics to the galaxy as far as radio-frequency emission is concerned.

\section{THE ATLANTIDE EXPEDITION}

IN June 1945 the Danish sculptor, Mr. Viggo Jarl, wrote to the University of Copenhagen to place his three-masted auxiliary motor-yacht Atlantide at the disposal of the University for a scientific expedition lasting up to ten months. Mr. Jarl not only undertook to finance the running of the ship but also allocated a sum of $10,000 \mathrm{kr}$. towards the scientific equipment.

Following this generous offer, plans were drawn up for an expedition off the coasts of tropical West Africa under the leadership of Dr. A. F. Bruun, of the Zoological Museum, University of Copenhagen, who was to have as colleagues two young zoologists, Mr. Jørgen Knudsen and Mr. Torben Wolff. Furthermore, when Prof. A. V. Hill, then secretary of the Royal Society, was on a visit to Copenhagen in June 1945, the plans for the expedition were widened. Prof. R. Spärck, head of the Zoology Department, proposed to Prof. Hill that the British Museum (Natural History) should be invited to collaborate in the work of the expedition. As a result, Dr. F. C. Fraser joined Mr. Jarl and the Danish scientists as the representative of the Museum.

The Atlantide sailed from Copenhagen on October 3 , 1945, and returned on June 17, 1946. During her time at sea, 170 stations were worked, mainly between the Canary and Cape Verde islands, off French Guinea, Sierra Leone, Liberia, the Ivory and Gold Coasts, Nigeria, French Equatorial Africa, the Belgian Congo, Angola, Gambia and Senegal. The gear used for collecting the benthic organisms included otter and Agassiz trawls and various dredges, while Van Veen and Petersen grabs were used for bottom samples. Hauls for plankton and neckton were made with one-metre and two-metre stramin nets and a Nansen standard plankton net. In addition, hydrographic observations were made off the Gold Coast and Nigeria.

* Atlantide Reports: Scientific Results of the Danish Expedition to the Coasts of Tropical West Africa, 1945-1946. Report No. 1. Pp. $247+16$ plates. $35 \mathrm{kr}$. Report No. 2 . Pp. $303+2$ plates. $40 \mathrm{kr}$. (Copenhagen: Danish Science Press, Itd., 1950-1951.)
It is at once evident from Dr. Bruun's introductory report that the Atlantide Expedition was efficiently organized. At least three hundred species of fishes. were taken, which is well over half the number known off the African coasts from Gibraltar to Cape Town. When this collection of fishes has been reported on, it must not only add to knowledge of the distribution and biology of the West African fauna but should also be of value to fisheries biologists at work in this area.

During the Expedition, attempts were made to harpoon the very elusive Delphinidæ, and eventually one was taken. This proved to be a male of the littleknown species Stenella frontalis (Cuvier) and it is described by F. C. Fraser in Atlantide Report No. 1. The close comparative study of this dolphin in relation to other members of the genus has shown very clearly that the systematics will not be satisfactorily appreciated until a much larger series of individuals is at hand, together with observations on sex and the external and internal anatomy.

The anatomy of the urinogenital tract in this dolphin is described by L. Harrison Matthews. While the relationships of these organs in the Odontoceti show a general degree of conformity, Matthews clearly traces the resemblances of the male urinogenital tract of Stenella to that of other dolphins. Although this might have been expected, the paper shows that there are most interesting problems in the comparative anatomy of the urinogenital tract of the Cetacea. awaiting further study.

A paper by Jørgen Knudsen on the egg capsules. and development of the prosobranch molluses has. the freshness of approach which we have come to. expect from the Danish biologists working on the reproductive larval ecology of invertebrates. Of the thirty-two species examined, twenty-two were found to have a non-pelagic development, whereas the remainder had a pelagic phase. 'This high proportion of species without pelagic larvæ is more like that found in colder waters than in the tropics, where species with pelagic larvæ are usually predominant. Knudsen suggests that this may be correlated with two environmental factors: first, the system of currents which would tend to carry planktonic larvæ away from settling areas, and secondly, the 'poor supply of planktonic food occasioned by the low nutrient-salt content of the Guinea Current.

Finally, in Atlantide Report No. 1, there are papers by Torben Wolff on the bird collection, by Bengt Hubendick on geographical variation in Siphonaria pectinata (L.), and by F. Jensenius Madsen on the Asteroidea. From a statistical study of shell characters, Hubendick finds a cline in the number of radii in the sculpture and in the pattern of the shell, and points out that this appears to be the first account of such variation in marine invertebrates. Madsen's well-illustrated systematic account of the starfishes contains descriptions of two new species of Astropecten and one new species of Luidia.

In Atlantide Report No. 2, the Echinoidea are reported on by Th. Mortensen, who describes a new species of Brissopsis nearly allied to the West Indian $B$. elongata, a further indication of the close relationship between the African and West Indian echinoids. The greater part of the report is taken up with papers by L. B. Holthuis on the caridean Crustacea and by D. M. Reid on the gammarid and caprellid Amphipoda.

The large collection of Caridea contains more than half the number of known species from tropical West African waters, many being represented by a good 